\title{
INTERCULTURAL COMMUNICATION IN TEACHING CHINESE TO EUROPEAN STUDENTS
}

\author{
Eva-Nicoleta, BURDUȘEL ${ }^{1}$, Song, SHAOFENG ${ }^{2}$ and Li, CAIYUE ${ }^{3}$ \\ 1,'Lucian Blaga" University of Sibiu, Sibiu, Romania, e-mail eva.burdusel@ulbsibiu.ro \\ ${ }^{2}$ Beijing Language and Culture University Confucius Institute, China, e-mail songsf08@hotmail.com \\ ${ }^{3}$ Beijing Language and Culture University Confucius Institute, China, e-mail licaiyue@yahoo.com
}

\begin{abstract}
The major goal of the present study is to highlight to tight connection and interdependency between language and culture from both theoretical and applied perspectives, with special focus on the reciprocal influence and impact on teaching Chinese language and literature to foreign students, particularly in the European context. Famous scholars have wisely noted the sine-quanon relation of society, culture, history, geography and language evinced in the process of communication, at large, and most notably in translation, literary studies and language learning, which are complex processes requiring a thorough and conscious immersion in the context of the language. The paper also includes a case study on teaching Chinese language and culture to foreign students.
\end{abstract}

KEY WORDS: intercultural communication, teaching Chinese to foreign students, best practice

\section{A CULTURAL APPROACH TO FOREIGN LANGUAGE TEACHING}

The major goal of the present study is to highlight to tight connection and interdependency between language and culture from both theoretical and applied perspectives, with special focus on the reciprocal influence and impact on teaching Chinese language and literature to foreign students, particularly in the European context.

Famous scholars have wisely noted the sine-qua-non relation of society, culture, history, geography and language evinced in the process of communication, at large, and most notably in translation, literary studies and language learning, which are complex processes requiring a thorough and conscious immersion in the context of the language. This theory is reinforced by Umberto Eco, in his landmark study Experiences in Translation, who defines translation as a "shift, not only between two languages, but between two cultures - or two encyclopedia ... translating is not only connected with linguistic competence, but with intellectual, psychological and narrative competence." [1] It has become widely accepted, that "a society`s language is an aspect of its culture ... The relation of language to culture is that of part to whole." [2] As sociologist Peter Trudgill noted: "these two aspects of language behavior are very important from a social point of view: first, the function of language in establishing social relationships, and second, the role played by language in conveying information about the speaker." [3] Furthermore, language is not only a social phenomenon but it is also culturally bound in its function as vehicle for conveying thoughts and communicating feelings: "language, then, is the heart within the body of culture, and it is the interaction between the two that results in the continuation of life-energy." Susan
Bassnett's statement endorses the firm argument set forth by Edward Sapir and Benjamin Lee Whorf that "no language can exist unless it is steeped in the context of culture; and no culture can exist which does not have at its center, the structure of natural language." [4] In his study on Culture, Language and Personality, Edward Sapir reinforced the idea that "language is a guide to social reality" and "no two languages are ever sufficiently similar to be considered as representing the same social reality. The worlds in which different societies live are distinct worlds, not merely the same world with different labels attached." [5]

Since our main focus in discussing intercultural communication is on the teaching of Chinese worldwide, and particularly in Europe, let us further examine some of the major challenges encountered in the exchange of ideas, at an individual level, or the more formal educational process, at an institutional level. In this respect, the case of Confucius Institutes and their astonishing development is relevant for the outstanding methods, contribution and impact in meeting the needs of increasingly number of people worldwide to acquire competence in Chinese language and culture. The reasons an individual is motivated to learn a foreign language are rooted in cultural as well as economic background, it has to do with much more than mere curiosity about what is foreign and distant, or even academic pursuit. "When a country is on the rise, a virtuous circle of expanding influence tends to develop. As China grows more powerful, more and more people want to know about it, read about it, watch television programmes about it and go there as tourists ... Wealth and economic strength are preconditions for the exercise of soft power and cultural influence."[6]

In his highly influential book, When China Rules the World, British journalist and academic Marting Jacques provides an 39 
insightful comment on such a difference in meaning, with cultural and linguistic implications, stemming from different conceptualization systems:

For the West the key operational concept is the nation-state, but for the Chinese it is the civilization-state ... whereas in English there are different words for nation, country, state and government, these are not only relatively recent in Chinese, but the Chinese still largely use the same character for 'country' and 'state'. The real difficulty, of course, lies not in linguistic differences but in the different cultural assumptions and meaning that are attached to those words in the two languages. The same word can have a very different meaning for an American or a French person in contrast to a Chinese, even though they might appear to be singing from the same sheet. [7]

Ever since they were initially set up, Confucius Institutes emphasized the idea of partnership, not only at managerial level, but also in terms of mutual learning and understanding, creating a platform for educational and cultural exchange. As Prof. Mote clarifies in a 2013 interview:

Culture determines about everything. If we want to examine a country, and determine whether it is going to succeed in its scientific and technological goals, the most important thing that determines the outcome is the country`s culture. It's not the number of engineers, nor the investment in research; it's the culture of the country. Culture is critical to everything we do. Culture is going to have a profound influence whether we do things right or not. The connection of language and culture is critical. And maybe learning a language is helped by learning the culture, too. Indeed, so much culture is changed by language. The combination of language and culture makes complete sense. [8]

\section{CASE STUDY}

The case study included in the present paper refers to the academic experience of one member of the teaching staff affiliated with the Confucius Institute at Lucian Blaga University of Sibiu set up in partnership with Beijing Language and Culture University. Enabled by the project of training nonEnglish speaking Chinese language teachers, in April 2010, she came to "Lucian Blaga" University to learn Romanian language, culture and civilization, in the framework of an intensive study programme of one and a half years, at the same time practicing to teach Chinese language and culture to Romanian students. For the past five years, she has been teaching Chinese to the primary school students and the Chinese major students in "Lucian Blaga" University, and currently she is teaching Chinese in Pitesti, there are more than 500 students learning Chinese, from three primary schools, and three middle high schools.

The added value of this paper is illustrated by a questionnaire addressed to 31 students affiliated to one high school in Pitesti, who have been learning Chinese for two months. All of them responded to the seven questions included in the questionnaire, mentioned below:

Question 1: Why do you want to learn Chinese?

Question 2: Before you began learning Chinese, what was your opinion about this language?

Question 3: After studying Chinese for two months, what is your opinion about Chinese language now?

Question 4: What is the most difficult part in learning Chinese?
Question 5: What do you think about Chinese characters?

Question 6: What do you expect to learn from the Chinese class?

Questions 7: Do you want to continue studying Chinese after you graduate high school?

For the first question, $52 \%$ of them want to learn Chinese because they think Chinese is interesting, 39\% of them want to learn something new and different, $9 \%$ of them want to visit China and study Chinese as major in university.

As regards direct experience in teaching Chinese to European students, one major difference between Chinese and Romanian is that Chinese language has two systems: i.e. phonetic and written. For the phonetic system, four tones are the most musical but hardest; many students can't distinguish them. For example: $m \bar{a}$, má, mă, mà. Different tones have different meanings, $m \bar{a}$ means mother, má means flax, mă means horse, mà means scold. Sometimes the students made interesting mistake when they could not identify the right "tone". Once a student asked me: "Mrs Li, can I kiss you?" I was shocked, and answered: "why?" the student said: "Because I don't understand..." Finally I realized that he wanted to ask me a question. But in Chinese "ask (Wèn)" and "kiss (Wěn)" have different tones , "ask (Wèn)" is the fourth tone, and "kiss (Wěn)" is the third tone. After I explained that, he understood the differences between, and paid much more attentions to the tones.

Besides the four tones, Chinese characters represent another major difficulty for students embarking on the study of Chinese language. When I addressed the question "Which one do you think is the most difficult to learn in Chinese? A: Pronunciation; B: four tones; C: Chinese grammar; D: Chinese character" $67 \%$ students chose Chinese characters. In order to make the characters more interesting and easier for them to understand, teaching experience has proven that cards or Power-point presentations help the students better understand them. Many students told me the Chinese characters look like pictures, and calligraphy is an art of Chinese character, so in the Chinese class, they also learn to use Chinese brush to paint Chinese characters.

Students usually ask about their equivalent Chinese names, but actually there are not direct translations. Pronunciations of foreign names are often meaningless in Chinese. The teacher usually gives the students Chinese name not just from the pronunciations, but also make them sound more Chinese. For example: there is a Romanian boy in my class, whose name is B. D., his Chinese name is Bù Dàliǔ (布大柳). It doesn't translate just from the sound, Dàliǔ in Chinese means "big willow" which means cherish friendship in ancient China.

Besides language teaching, students are also introduced to Chinese culture, social customs and habits. Learning a language is inseparable from its own culture and the culture also can make the class more lively and interesting. The questionnaire shows that $71 \%$ students want to learn about different cultures in the Chinese class.

In Chinese culture, the most common greeting way is to shake hands, people seldom hug each other or kiss on cheeks. After I came to Romania, I realized that hug each other or kiss on cheeks is a polite way to greet to your friend thus showing that you have a good relationship. By now I got used to this kind of greeting. 
Another example, which I discussed with my students referred to the way Chinese people greet each other when they on the street. I told them if a Chinese meet you on the street and asked: "Have you eaten?" or "Where are you going?" It doesn't mean that he wants to invite you for a dinner or really care about where you are going, it's just like Romanian people say "salut". Students should not feel strange or offended as if the question intruded their individual privacy.

Intercultural communication is an on-going process, it does only happen in the classroom. When I first arrived in Romania, I also experienced something that I did not even know how to respond: whether to laugh or cry. Some students gave me a bouquet of chrysanthemums as gift. In Chinese culture, the chrysanthemum is generally used at funerals, showing respect to the dead. Due to the different cultures, the students were not aware of that. There are also various taboos in gift-giving customs in China. Such as do not offer an alarm-clock or watch as a gift to people in China, because the Chinese pronunciation for clock is "zhong" which means stop, and looking forward someone's death. There are many cultural differences between China and Romania, usually by the end of each class, the teacher chooses to discuss one topic with the students, and they find more information by themselves, and compare afterwards.

To sum up this case study, intercultural communication is an essential part of Chinese language teaching; as a Chinese teacher in Romania, awareness of the importance cultural communication and the ability to actively solve problems encountered prove to be important skills.

\section{CONCLUSIONS}

To conclude the present study, let us refer to a recent interview with $\mathrm{Xu}$ Zechen, Writer and Novelist of the Year of the $13^{\text {th }}$ Mass Media Award for Chinese Literature, who commented on the intercultural communication in the literary field and the fact that knowledge of other cultures enables the reader to understand not only the text but also the context.
... as the new century dawned, people no longer cared as much as before about whether belonged to them or others. Against the background of globalization, literature could no longer be bound by national boundaries. A writer must pay attention to world events, all types of subject matter, all kinds of techniques and everything that is related to literature. Literature has become a public resource that is shared by everyone ... In this sense, we can say that, for culture, 'the more diversified it is, the more it belongs to the world.' Only when you have provided variety, can you become part of the global ecosystem ... What is literature? I believe it can be summarized in three terms: a sense of strangeness in content, a sense of strangeness in art, a sense of strangeness in ideology. [9]

\section{REFERENCES}

1. Umberto Eco, Experiences in Translation, University of Toronto Press, translated by Alastair McEwen, University of Toronto, Toronto, Buffalo, London: 2001, pp.17, 13

2. R.A. Hudson, Sociolinguistics, Cambridge University Press, 2004, p.79

3. Peter Trudgill, Sociolinguistics: An Introduction to Language and Society, Penguin Books, 1983, p. 14

4. Susan Bassnett, Translation Studies, London: Routledge: 1998 , p. 22

5. Edward Sapir, Culture, Language and Personality qtd in Susan Bassnett, Translation Studies, London: Routledge: 1998, p. 21

6. Martin Jacques, When China Rules the World, The Penguin Press, New York: 2009, p. 403

7. Idem, p. 227

8. Interview with Prof. CD Mote, former President of the university of Maryland, in Confucius Institute Magazine, volume 27, no 4/ July 2013, p.33, print and online issue

9. Interview with $\mathrm{Xu}$ Zechen, Writer and Novelist of the Year of the $13^{\text {th }}$ Mass Media Award for Chinese Literature, in Confucius Institute Magazine, volume 41, no 6/ November 2015, p. 31, print and online issue 